\title{
Study on Talent Training Mode for Hotel Management Specialty in Higher Vocational Colleges Based on Market Orientation
}

\author{
Zhi Zhang \\ Wuhan City Vocational College, Wuhan, 430064, China
}

Keywords: Market orientation, Higher vocational colleges, Hotel management, Professional talents.

\begin{abstract}
As China's hotel industry accelerates to develop, the demand of Chinese tourism enterprises for talents of hotel management specialty is also on the rise. Hotel management specialty of higher vocational colleges in China is gradually valued by the state. But in talent connection process, the problem of low connection between talents and enterprises' demand appears. This is mainly because higher vocational colleges fail to plan teaching in accordance with current situation and demand of hotel industry. Thus, hotel management talent training lacks actual effect and cannot adapt the need of social development. This will certainly influence follow-up development of students majoring in hotel management. Next, this paper will analyze and discuss the defects of hotel management education in higher vocational colleges and specific reform mode in detail, in the hope of assisting colleges to train high-quality hotel management talents who further comply with market demand.
\end{abstract}

\section{Introduction}

After national economy of China enters the new century, a new stage of booming development comes. Popular living quality is also improving. As cultural and economic exchanges of various countries deepen continuously, the scale of China's hotel industry is expanding continuously. According to the predication of relevant tourism departments, the scale of China's hotel industry will have expanded to at least 6 times of current figure by 2020. the demand for hotel management talents will also improve sharply. Hence, hotel management talent training in higher vocational colleges is an important link concerning future development of Chinese hotel industry. But in current talent market, high-quality excellent hotel management talents are rare, and current education mode of higher vocational colleges cannot well adapt the development demand of tourism market. Thus, hotel management talents of colleges and actual talent demand of hotel industry are disconnected. Only when higher vocational colleges really realize the problem and find out effective measures to facilitate reform of hotel management talent education in higher vocational colleges can more hotel management talents who comply with development demand be trained. Meanwhile, the development of hotel industry can be promoted.

\section{Problems of hotel management talent training in higher vocational colleges}

In recent years, many higher vocational colleges in China have actively reformed talent training mode and continuously explored new measures to drive long-term and stable development of hotel management specialty. However, the disconnection between hotel management talent education of higher vocational colleges and actual demand of hotel market is prominent all the time. This is mainly reflected in the following aspects:

Firstly, professional talent training positioning breaks away from the demand of hotel market. Some colleges are not clear about the target positioning of hotel management education. Even the training objective is too low and close to secondary vocational schools. Or the objective is too high and approaches the standard of universities. Higher colleges fail to fully know talent type urgently needed by hotel industry and professional skills ${ }^{[1]}$. 
Secondly, talent training work breaks away from social needs. Problems of multiple aspects exist in hotel management courses of Most higher vocational colleges, such as old-fashioned teaching method, insufficient course system effect, ignorance of practical training link and insufficient comprehensive teaching talents.

Thirdly, the communication between hotel enterprises and higher vocational colleges is insufficient. Most higher vocational colleges lack communication and cooperation with hotel enterprises, so colleges neither understand current industrial situation nor know the needs of current hotels. Therefore, hotel enterprises naturally do not approve the education of higher vocational colleges.

Fourthly, talent evaluation system is not sound. Most higher vocational colleges still judge the ability of professional talents in accordance with traditional evaluation and assessment mode, i.e. score-dominated. As long as students' score is qualified, they can graduate smoothly. But, students' professional ethics and working ability cannot be judged with scores. These are important occupational qualities in follow-up hotel work ${ }^{[2]}$.

In a word, if current hotel management specialty of higher vocational colleges cannot make sure the education mode complies with the development of hotel industry, they will be abandoned by hotel market and future society due to improper teaching plan even if they own good market prospect. Hence, hotel talent training of higher vocational colleges should be reformed and rectified according to development demand of hotel market.

\section{Talent training reform measures}

Pay close attention to the development of hotel industry and lay emphasis on survey.

Meticulous and comprehensive industrial survey on the industry is college teaching reform measure which can effectively improve marketability, sustainable development and occupation pertinence of talent training work. Meanwhile, it is also a core means to ensure talent training level. With the help of professional industrial survey, higher vocational colleges can more explicitly know and master development and future prospect of hotel industry and relevant enterprises. Besides, they can know the structure of hotel industry and the demand for the ability and quantity of professional talents so as to make sure course setting and teaching mode of hotel management specialty can better adapt development demands of the whole region, the whole industry and the whole society ${ }^{[3]}$. Furthermore, it is required to meticulously know vocational ability, professional quality and post standards of hotel industry and relevant enterprises and take these requirements as the norms to position teaching objective and talent training norms of this specialty. Besides, it is required to consider knowledge base, personality characteristics and development demand of students in this specialty as well as theoretical knowledge, skill level and professional quality to establish more rational professional course system. The survey results must be carefully studied and thought to finally get more accurate survey results and offer effective basis for teaching reform and improvement.

\section{To carry out targeted research and establish rational course system.}

The discussion of expects in organizational teaching field and hotel field on professional teaching is a major channel of promoting teaching reform. The conclusions and measures they gain in the discussion process are the theoretical basis of higher vocational colleges to rational set and develop professional courses, and they can guide hotel specialty of higher vocational colleges to plan teaching mode of professional courses by focusing on current development of hotel industry ${ }^{[4]}$. Hence, the practical implementation discussion activity of experts in multiple fields is very important for doing well education construction of hotel specialty and facilitating the development of hotel specialty education. These experts dabble in the knowledge in professional field more deeply, so they will certainly have dabble in for the whole market industry. They can master key emphasis of professional course system construction, formulate teaching content in a more detailed way in accordance with vocational ability training demand of professional posts, plan the teaching links oriented to students' 
future career development, establish fine and multi-level course system, make course setting more comply with practical conditions and improve students' learning effect. In this way, professional talents trained by higher vocational colleges will more comply with enterprises' demand for talents, and the overall quality of students can improve. Meanwhile, the harmony between talents and enterprise market can be promoted, and professional education can be further approved by enterprises.

\section{Intensify practical training and improve students' professional skill application ability.}

To make sure teaching content and teaching mode further comply with industrial demands, closer cooperation with relevant enterprises is required. Hence, colleges can reach cooperation with hotel enterprises in terms of teaching resource and post resource. Teaching resources mainly refer to the contents about students' theoretical knowledge and information. For instance, colleges may invite hotel enterprises to prepare professional teaching materials and teaching schemes together, improve advancement of textbook content with the help of expertise and epochal character of hotel enterprises, let teaching materials better connect with demands of hotel industry and let students learn useful knowledge in follow-up work ${ }^{[5]}$. Additionally, colleges can introduce magazines, newspapers, periodicals and literatures about hotel industry in the library so that students can know the latest development trend and information of hotel industry through literatures and then plan their learning objective with pertinence. Post resources mainly refer to cooperation in terms of practical training. To train professional hotel management talents, it is required to let students contact employment experience link of hotels and then make sure students can clearly cognize future work, specify their position, know well work environment, accumulate relevant work experience and improve their professional ability and professional quality. Generally speaking, field visit and experience link can effectively help students improve their practical operation ability and deepen their understanding of enterprises and industry market, but such short-time contact cannot let students directly take the post after their graduation. Thus, higher vocational colleges are very necessary to let students carry out deeper intensive learning before their graduation. For example, higher vocational colleges may arrange students to practice for a half year before they graduate so as to make sure they can fuse in the enterprises before their graduation, start to experience the process of becoming an employee, improve their professional skills and enhance their ability to solve problems. In this process, off-campus internship base building should be enhanced. Representative real enterprises with advanced level in hotel industry must be chosen so as to establish cooperative relationship and make sure students can more deeply understand and master hotel management idea and working process, train good professional quality and better apply the skills and knowledge in the work as well as improve their work efficiency and competitiveness in the working environment with rich cultural deposits where students can learn skills and knowledge. Such resource cooperation is win-win for both higher vocational colleges and hotel industry and is beneficial to future development of both.

\section{Intensify teaching staff building and guarantee teaching quality.}

Teaching executors of each college and each specialty are the most important core factor which decides the final teaching result. Such teaching executors are teaching staffs in colleges. Only when there are high-quality excellent teaching staffs with rich professional knowledge and adequate practical experience can the teaching progress of hotel specialty be effectively driven. Meanwhile, teaching effect can be ensured, and a solid foundation can be laid for training practical talents. But seeing from the teaching team of hotel management specialty in higher vocational colleges, most of these teachers do not own sufficient practical work experience of hotel industry, and many teachers repeat what the textbook says. Thus, if higher vocational colleges make sure their students can comply with the requirements of industry market, they should first build practice-based and interaction-based excellent teaching team. Colleges should actively encourage teachers to take a temporary post and practice in hotel industry and strive to improve their professional knowledge and practical application ability. In this way, teaching staffs will own rich theoretical knowledge and strong practical application and guidance ability. Besides, it is required to fully know development trend and future tend of hotel industry so as to improve teaching content according to the situation and communicate industry information with epochal character and practical value to students. Secondly, colleges can 
employ professional talents with rich working experience from hotel industry as professional teachers for targeted guidance. Finally, colleges should often organize teachers to participate in exchange meeting and training about industry knowledge so as to make sure they can impart more practical knowledge to students anytime.

\section{Establish evaluation system oriented to vocational development.}

Evaluation and assessment standards of hotel management specialty in higher vocational colleges should keep uniform with hotel talent assessment standards. Hotel management education of higher vocational colleges should be based on market demand, reform in allusion to traditional assessment mode and develop more effective evaluation mode. In accordance with the features of higher vocational education and future development demands of hotels and market, it is required to highlight the integration of enterprise assessment and college assessment, establish accurate and fair professional skill checking and ability evaluation system, reform college teaching result evaluation mode and standards, and improve assessment content, form and result by taking professional skill training as the core. In addition, it is required to intensify examination system reform, pay attention to test and evaluation of students' practical ability, reform traditional evaluation mode by taking professional skill assessment as the core, regarding evaluation system as the guidance of examination process, and form a checking system which combines practical ability evaluation and theoretical knowledge evaluation. In the aspect of course mode, it is required to make open course education mode which integrates common assessment and conclusive assessment as well as theoretical knowledge training, oral test and vocational skills, and teaching evaluation system richer.

\section{Conclusion}

In one word, to get better development of hotel management specialty of higher vocational colleges, real-time development trend of hotel industry should be valued, and current market development demand serves as guidance of teaching work to properly improve talent training mode so as to make sure it complies with the requirement of era development. Besides, it is required to further intensify students' professional ability training and ideological quality edification, make students better adapt hotel industry and relevant posts and continuously seek talent training mode which is connected with society. In this way, more excellent talents can be trained.

\section{References}

[1] Ni Xiaoli, Exploration on market-oriented hotel management talent training mode of higher vocational colleges, Oriental Enterprise Culture, 2014(10):278-278.

[2] Zhou Zhihong, Study on market-oriented hotel management talent training mode of higher vocational colleges - case study of Huatian Tourism and Hotel Management College, Hunan Normal University, 2009.

[3] Wang Miaomiao, Study on market-oriented hotel management talent training mode of universities, Qingdao University, 2011.

[4] Li Changqiu, Study on current situation and countermeasures of hotel management talent training mode of higher vocational colleges, Vocational Education Research, 2011(3):27-28.

[5] Zhou Danong, Zhou Li, Thought on innovative talent training of hotel management specialty in higher vocational colleges, Education and Vocation, 2012(12):108-110. 